\title{
Expression of the insulin-like growth factor (IGF) system in the bovine oviduct at oestrus and during early pregnancy
}

\author{
P. G. A. Pushpakumara ${ }^{1}$, R. S. Robinson ${ }^{1}$, K. J. Demmers ${ }^{2}$, \\ G. E. Mann², K. D. Sinclair ${ }^{3}$, R. Webb ${ }^{2}$ and D. C. Wathes ${ }^{1 *}$ \\ ${ }^{1}$ Reproduction and Development Group, Royal Veterinary College, Hawkshead Lane, North \\ Mymms, Hatfield, Hertfordshire AL9 7TA, UK; ${ }^{2}$ Division of Animal Physiology, School of \\ Biosciences, University of Nottingham, Sutton Bonington, Loughborough, Leicestershire \\ LE1 2 5RD, UK; and ${ }^{3}$ Department of Applied Physiology, Scottish Agricultural College, \\ Craibstone Estate, Aberdeen AB21 9YA, UK
}

Early mammalian embryo development in vitro can be enhanced by co-culture with oviductal cells and by the addition of insulin-like growth factors (IGFs). This study examined the expression patterns of the oviductal IGF system in cattle in relation to the number of days after oestrus and the presence or absence of embryos. Oviducts were collected from: (i) 66 nulliparous heifers on day 3 , day 6 or day 16 after insemination and from (ii) ten nonpregnant, lactating cows on day 0 or day 1 of the oestrous cycle. Oviducts were coiled, frozen whole and sectioned for in situ hybridization. Expression patterns of mRNAs encoding IGF-I, IGF-II, type 1 IGF receptor (IGF-1R), and the IFG binding proteins (IGFBP)-1, -3 and -5 were determined from autoradiographs. Separate measurements were made for the mucosa and muscle layers of the infundibulum, ampulla and isthmus. None of the parameters measured differed between heifers with or without the presence of an embryo. mRNAs encoding IGF-I and IGF$1 R$ were present in the mucosa and muscle of all three oviductal regions, and the highest value of IGF-I mRNA was measured in heifers on day 3. IGF-II mRNA was expressed predominantly in the muscle wall. IGFBP-1 mRNA was not detectable, whereas mRNAs encoding IGFBP-3 and -5 were expressed in both the muscle and mucosa. IGFBP-3 expression was higher in cows on day 0 and day 1 of the oestrous cycle than in heifers on day 3 , day 6 and day 16 after insemination. A peak of IGFBP-5 expression was reached on day 6 . Locally or systemically produced IGFs, regulated by IGFBPs, may act directly on the embryo or indirectly via modulation of oviductal secretions and muscular activity to influence the success of early embryo development.

\section{Introduction}

The mammalian oviduct plays a critical early role in the establishment of a successful pregnancy, even though the time that the gametes and embryos spend within the oviduct is brief (generally 3-4 days) (for a review, see Hunter, 1988). The ampulla and isthmus participate in sperm transport at oestrus, whereas the infundibulum collects the ovum from the ovarian surface after ovulation. Fertilization, cleavage and development to the 8-16-cell stage take place within the ampulla. The embryo then passes quickly through the isthmus and enters the uterus. Early embryonic development is therefore dependent on the factors present in the oviductal fluid.

In early studies in vitro, bovine embryos failed to develop beyond the eight-cell stage when they were cultured alone, but this developmental block could be overcome by coculture with various somatic cells (Camous et al., 1984;

${ }^{*}$ Correspondence

Email:dcwathes@rvc.ac.uk
Bavister, 1988). The co-culture system may improve viability by removing noxious influences. In addition, members of the insulin-like growth factor (IGF) system may be synthesized by the somatic cells and could therefore contribute to the more conducive environment in co-culture. The IGF system comprises two ligands (IGF-I and -II), two receptors (IGF-1R and $-2 \mathrm{R}$ ) and six binding proteins (IGFBP-1 to -6). IGF-I and -II are single chain polypeptides with three intra-chain disulphide bonds (Daughaday and Rotwein, 1989). They are structurally similar to pro-insulin and stimulate a wide range of mitogenic and anabolic effects (for reviews, see Zapf and Froesch, 1986; Jones and Clemmons, 1995) through binding to IGF-1R (for reviews, see Rechler and Nissley, 1985; LeRoith et al., 1995). IGFBPs are a family of six binding proteins that bind IGF-I and -II with an affinity greater than that of the IGF receptor and which regulate the bioavailability of the IGFs to bind to the receptors (Rechler and Clemmons, 1998). Circulating IGFs and IGFBPs are synthesized and secreted primarily by the liver (Scharf et al., 1996), although many extra-hepatic tissues also participate. The reproductive tracts of a variety of species are known sites of IGF production, for example, the uterus in rats 
(Murphy et al., 1987), pigs (Simmen et al., 1991), cows (Geisert et al., 1991; Robinson et al., 2000) and sheep (Stevenson et al., 1994), and the oviduct in humans (Giudice et al., 1992), cows (Schmidt et al., 1994; Winger et al., 1997), sheep (Stevenson and Wathes, 1996) and pigs (Wiseman et al., 1992). A particular feature of the IGF system is that the production of many of its components can be regulated by nutrition (McGuire et al., 1992; Roberts et al., 1997). This finding raises the possibility that metabolic status could alter oviductal activity via modulation of the IGF system.

Studies in vitro have shown that the oviduct contains a number of growth factors that can stimulate cellular proliferation and differentiation of preimplantation embryos (for a review, see Heyner, 1997). These factors include members of the epidermal growth factor (EGF) and transforming growth factor $\beta$ (TGF $\beta$ ) families (Dalton et al., 1994; Zhao et al., 1994) in addition to the IGFs and their binding proteins. Several lines of evidence indicate a role for the IGFs in the preimplantation period. The anabolic and mitogenic influences of IGF-I on murine preimplantation development are well characterized (Kaye et al., 1992). Studies have indicated that IGF-I exerts a beneficial effect on the development of early pig embryos in vitro (Xia et al., 1994). However, results from bovine studies are not as clear. Although some studies indicate that IGF-I has little influence on developmental frequencies (Larson et al., 1992), other studies report dose-responsive influences on development of bovine zygotes to the blastocyst stage (Herrler et al., 1993; Palma et al., 1997).

According to this evidence, it is clear that the oviducts of various species including cattle express transcripts for IGF ligands, IGF-1R and IGFBPs. However, there have been no detailed studies to determine the sites of expression or to examine the effects of factors, such as pregnancy or stage of the oestrous cycle, on the IGF system in the bovine oviduct. Studies in this area are potentially important because of the high incidence of early embryo mortality in this species (Wathes, 1982). Therefore, the objectives of the present investigation were to localize and characterize the spatial and temporal expression patterns for IGF-I, IGF-II, IGF-1R and IGFBPs $(-1,-3$ and -5$)$ in the bovine oviduct at oestrus and during early pregnancy.

\section{Materials and Methods}

\section{Animals and management}

Sixty-six nulliparous Simmental $\times$ Holstein/Friesian heifers (study A) and ten multiparous mid-lactation Holstein/ Friesian dairy cows (study B) were used in this study. Samples from both studies were analysed together at the same time. All experiments were conducted under the Animals (Scientific Procedures) Act 1986.

In both studies, tissue was collected on specified days of the oestrous cycle after a synchronization regimen. For the heifers in study $A$, the regimen started on day 1 with the insertion of a controlled internal drug releasing (CIDR) device (1.9 g progesterone intra-vagina; SmithKlineBeecham Animal Health, Tadworth). On day 6, each heifer was injected i.m. with $500 \mu \mathrm{g}$ prostaglandin (Estrumate; Coopers Animal Health, Crewe, Cheshire). The CIDR device was removed 5 days after the prostaglandin injection (day 11). A second dose of prostaglandin was administered 15 days later (day 27) and the heifers were given timed artificial inseminations (Al) twice at 72 and $90 \mathrm{~h}$ after the second prostaglandin injection. The heifers were killed on day 3 $(n=25)$, day $6(n=24)$ or day $16(n=17)$ after $\mathrm{Al}$ and the reproductive tracts (the oviduct, uterus or both, depending on the day the heifers were killed) were flushed with normal saline to determine the presence of viable embryos. Oviducts were then coiled and frozen in liquid nitrogen. Once frozen, the oviducts were wrapped in aluminium foil, transported to the laboratory in dry ice and stored at $-80^{\circ} \mathrm{C}$.

The mature cows in study B were synchronized by i.m. administration of $500 \mu \mathrm{g}$ prostaglandin in the mid-luteal phase of the oestrous cycle, which was monitored using milk progesterone radioimmunoassay (Bulman and Lamming, 1978). The cows were killed when signs of oestrus were observed (day $0, n=6$ ) or on the day after observed oestrus (day $1, n=4$ ). Ovaries of the day 0 cows contained preovulatory follicles, whereas the ovaries from the day 1 cows showed a recent ovulation point. Oviducts ipsilateral to the preovulatory follicle or corpus haemorrhagicum were collected and processed as above.

\section{Oligonucleotide probes}

All probes used were single-stranded oligonucleotides (Babraham Institute, Cambridge) (for details see Table 2). The probes used have been validated previously for use in cows (Robinson et al., 2000). Sense probes were always included as negative controls and any signals from these probes were regarded as non-specific.

\section{Localization of mRNA by in situ hybridization}

The in situ hybridization technique was performed as described by Stevenson et al. (1994) and Robinson et al. (2000). Briefly, sections were fixed in $4 \%(w / v)$ paraformaldehyde, dehydrated in ethanol and stored at $4{ }^{\circ} \mathrm{C}$ in ethanol. The oligonucleotide (5 ng) was end-labelled with $\left[{ }^{35} \mathrm{~S}\right] \mathrm{dATP}$ (Promega UK, Delta House, Chilworth Research Centre, Southampton) using deoxynucleotidyl transferase (Pharmacia Biotech, St Albans, Herts). A labelled probe $(100 \mu \mathrm{l}$, diluted to a final concentration of 1100000 c.p.m. $\mathrm{ml}^{-1}$ ) was added to each section and incubated at $42.5^{\circ} \mathrm{C}$ overnight. The following day, the slides were washed, airdried and exposed to $\beta$-max hyperfilm (Amersham International, Amersham, Bucks) for 14, 18 or 24 days (Table 1).

\section{Photographic emulsions}

Slides exposed previously to X-ray film were coated with photographic emulsions LM1 (Amersham International) 
Table 1. The sequence of the sense probes and exposure time for in situ hybridization X-ray films and emulsions of bovine ovaries

\begin{tabular}{|c|c|c|c|c|}
\hline \multirow[b]{2}{*}{ Probe } & \multirow[b]{2}{*}{ Sense sequence } & \multicolumn{2}{|c|}{ Exposure time (days) } & \multirow{2}{*}{$\begin{array}{c}\text { Similarity } \\
\text { to bovine } \\
\text { gene }(\%)\end{array}$} \\
\hline & & X-ray film & Emulsions & \\
\hline \multirow[t]{2}{*}{ IGF-I } & 82-126 of ovine IGF-I gene (Wong et al. 1989) & & & \\
\hline & 5' GTC ACA TCC TCC TCG CAT CTC TTC TAT CTG GCC СTG TGC TTG CTC 3' & 18 & 24 & 98 \\
\hline \multirow[t]{2}{*}{ IGF-II } & 95-124 of ovine IGF-II gene (O'Mahoney and Adams, 1989) & & & \\
\hline & 5’ CCA GCG AGA CTC TGT GCG GCG GGG AGC TGG 3' & 18 & 24 & 100 \\
\hline \multirow[t]{2}{*}{ IGF-1R } & 352-396 human IGF-1R gene (Ullrich et al. 1986) & & & \\
\hline & 5' CTC ACG GTC ATC CGC GGC TGG AAA CTC TTC TAC AAC TAC GCC CTG 3' & 18 & 24 & * \\
\hline \multirow[t]{2}{*}{ IGFBP-1 } & 779-823 of bovine IGFBP-1 gene (Sneyers et al. 1991) & & & \\
\hline & 5’ GGA GAG CCT GGG CTC TGT TGG TGT GTC TAC CCT TGG AGT GGG AAG 3' & 24 & ND & 100 \\
\hline \multirow[t]{2}{*}{ IGFBP-3 } & 544-573 of bovine IGFBP-3 gene (Spratt et al. 1991) & & & \\
\hline & 5' GAC CAC AGC ATG GGG AGC ACA GAG AAC CAG 3' & 24 & 36 & 100 \\
\hline \multirow[t]{2}{*}{ IGFBP-5 } & 291-335 of bovine IGFBP-5 gene (Moser et al. 1992) & & & \\
\hline & 5' CTA CTC GCC CAA GAT CTT CCG GCC CAA GCA CAC CCG CAT CTC CGA 3' & 14 & 21 & 100 \\
\hline
\end{tabular}

*The bovine sequence in this region has not yet been sequenced but the region selected is highly homologous between other species. ND: not studied.

IGF: insulin-like growth factor; IGF-1R: type 1 IGF receptor; IGFBP: IGF binding protein.

Table 2. Insulin-like growth factor (IGF)-I and type 1 IGF receptor (IGF-1R) mRNA expression (mean absorbance values) in the oviducts of heifers in study $\mathrm{A}$

\begin{tabular}{|c|c|c|c|c|c|c|}
\hline Region & Tissue & Day 3 & Day 6 & Day 16 & Pooled SE & $P$ \\
\hline IGF-I (n) & & (25) & (24) & (16) & & \\
\hline \multirow[t]{2}{*}{ Ampulla } & Mucosa & 0.03 & 0.03 & 0.02 & 0.002 & 0.06 \\
\hline & Muscle & $0.07^{a}$ & $0.04^{b}$ & $0.02^{\mathrm{c}}$ & 0.003 & 0.0001 \\
\hline \multirow[t]{2}{*}{ Isthmus } & Mucosa & $0.06^{\mathrm{a}}$ & $0.04^{b}$ & $0.03^{b}$ & 0.002 & 0.0001 \\
\hline & Muscle & $0.11^{\mathrm{a}}$ & $0.04^{b}$ & $0.03^{b}$ & 0.004 & 0.0001 \\
\hline IGF-1R (n) & & $(21)$ & (23) & (16) & & \\
\hline \multirow[t]{2}{*}{ Ampulla } & Mucosa & 0.04 & 0.04 & 0.05 & 0.007 & 0.91 \\
\hline & Muscle & $0.04^{\mathrm{a}}$ & $0.05^{a b}$ & $0.05^{b}$ & 0.008 & 0.03 \\
\hline \multirow[t]{2}{*}{ Isthmus } & Mucosa & $0.06^{a b}$ & $0.05^{a}$ & $0.08^{b}$ & 0.012 & 0.03 \\
\hline & Muscle & 0.03 & 0.02 & 0.03 & 0.008 & 0.56 \\
\hline
\end{tabular}

abWithin rows, values with different superscripts are significantly different, $P<0.05$.

The number of animals $(n)$ studied at each stage for each probe is indicated.

according to the manufacturer's instructions and kept at $4^{\circ} \mathrm{C}$ for 21, 24 or 36 days (Table 1). The slides were developed in $20 \%(\mathrm{v} / \mathrm{v})$ phenisol, fixed in $1.9 \mathrm{~mol}$ sodium thiosulphate $\mathrm{I}^{-1}$ and counterstained with haematoxylin and eosin to confirm cellular localization of the radioactivity.

\section{Absorbance measurements}

Absorbance units were measured from autoradiographs for the mucosa and muscle layers for each of the three oviductal regions: infundibulum, ampulla and isthmus, although the infundibulum was not present in all sections. Measurements were made using a Seescan image analysis system (Seescan plc, Cambridge) as described by Stevenson et al. (1994). In brief, autoradiographs were projected on to a computer screen; the region of interest was encircled and the mean absorbance reading of this area was measured. The background absorbance, from a blank autoradiograph, was first subtracted automatically. The absorbance value for the sense section was subtracted from the corresponding antisense section. Readings were obtained from four sections per cow and a mean value of specific hybridization for each animal was calculated. The limit of detection was taken as an absorbance value of 0.01 . The intra-assay coefficients of variation (based on duplicate slides using the same probe) for the probes studied were as follows: IGF-I, $5.6 \%$; IGF-II, 7.2\%; IGF-1R, 6.8\%; IGFBP-3, 5.7\%; and IGFBP-3, 3.6\%. Sections for a particular probe, from both studies, were all analysed in a single assay to avoid any interassay variations. 

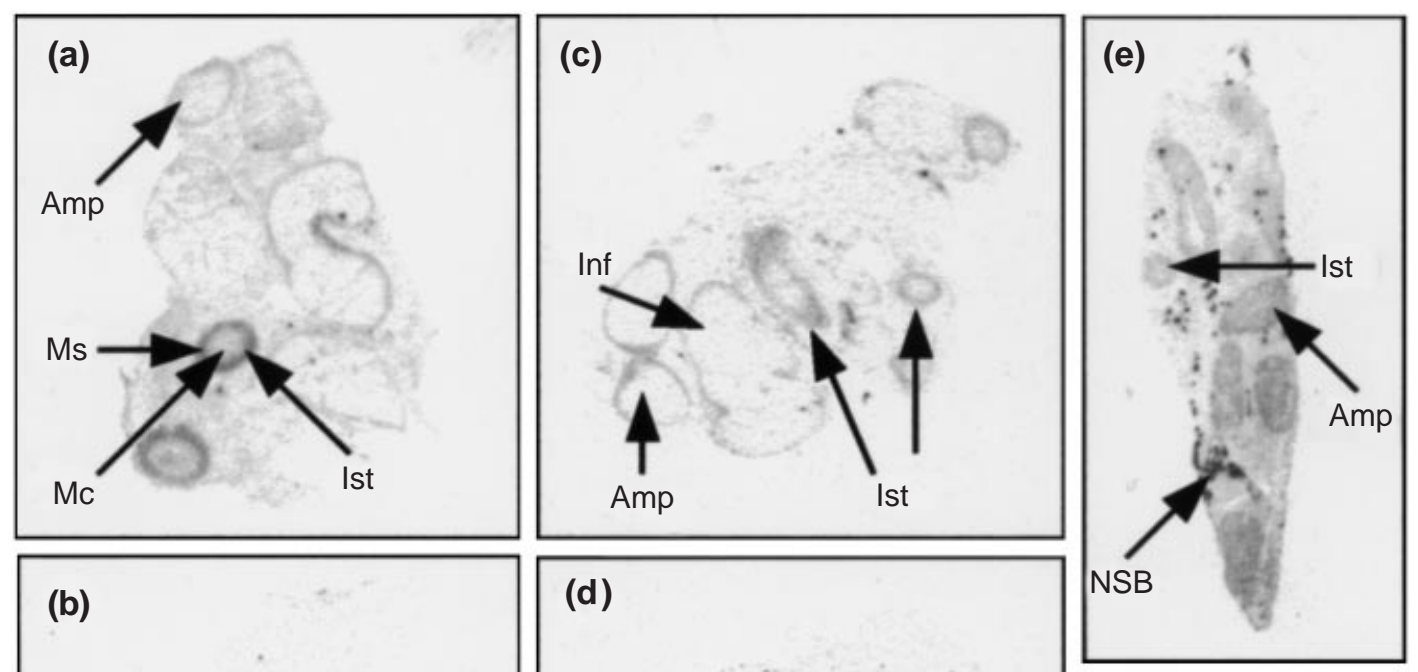

(b)

\section{(d)}

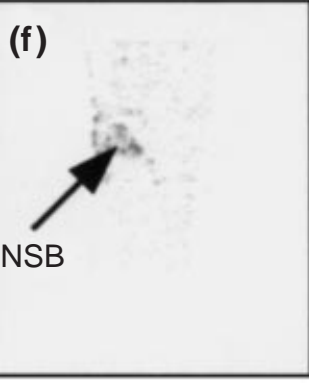

Fig. 1. The localization of mRNA encoding components of the insulin-like growth factor (IGF) system in the bovine oviduct. The photographs are oviduct cross-sections from autoradiographs showing the distribution of: (a) IGF-I (day 3), (c) IGF-II (day 3) and (e) type 1 IGF receptor (IGF-1R) mRNA (day 0, oestrus). Corresponding control sections probed with sense oligonucleotides are shown in: (b) IGF-I, (d) IGF-II and (f) IGF-1R. The transcripts for IGF-I were expressed in mucosa (Mc) and muscle (Ms) of the ampulla (Amp) and isthmus (Ist) as indicated by the arrows. The IGF-II mRNA showed strongest hybridization to the smooth muscle layers of ampulla, isthmus and infundibulum (Inf) as indicated by the arrows. The transcripts for IGF-1R mRNA were present in both muscle and mucosa. NSB: non-specific binding. Scale bar represents $1 \mathrm{~mm}$.

\section{Statistical analysis}

Statistical analysis was performed using SPSS (version 9). Data were checked for homogeneity of variance using Levene's test and log transformed if appropriate. Initial analysis of the data on the heifers (study A) was performed using GLM multivariate ANOVA (MANOVA) with day 3, 6 or 16 after $\mathrm{Al}$ and presence or absence of embryos as factors. The data on the cows (study B) were initially analysed by one-way ANOVA to compare the results on day 0 with day 1 . Finally, the data on the heifers from day 3 , day 6 and day 16 and the data on the cows from day 0 and day 1 were analysed together using one-way ANOVA to detect whether the expression pattern changed according to the day after oestrus. Where significance was demonstrated, differences between days were tested using LSD.

\section{Results}

In study $A$, the data for the number of heifers with an embryo present on each day were as follows: day 3 (14/25), day $6(12 / 24)$ and day $16(12 / 17)$. Data on each of these days were analysed according to the presence or absence of a viable embryo in the fluid used to flush the reproductive tract. No differences in the absorbance readings were detected in any particular oviductal region for any of the probes examined on any of the days. Therefore, on each of the three days, data were pooled from heifers with and without an embryo. These results are considered below together with those from the multiparous cows. Data on the infundibulum have not been included in the tables as fewer sections were examined, so quantification was less reliable.

\section{Distribution of IGF-I mRNA}

IGF-I mRNA was present in the mucosa and muscle of all three regions examined (Fig. 1a). Cellular localization of the signal using emulsion-coated slides showed that the IGF-I gene transcripts were localized mainly to the stromal fibroblast underlying the luminal epithelium in the mucosa and to the smooth muscle cells of the muscle wall in both the ampulla and isthmus (Fig. 2a). Expression of IGF-I 
mRNA in the heifers varied according to the days after Al and the highest expression was observed on day 3 (Table 2), particularly in the muscle layer. The values recorded in the mucosa of cows on day 0 and day 1 were similar to those found in heifers on day 3, whereas concentrations in the muscle were lower $(P<0.05)$ and equivalent to those found in heifers on day 6 (Table 3 ).

\section{Distribution of IGF-II mRNA}

The transcripts for IGF-II mRNA showed strongest hybridization to the smooth muscle cells of the muscle wall of both the ampulla and isthmus (Fig. 1c). However, transcripts were barely detectable in the mucosa of both regions. Expression of IGF-II mRNA in the muscle wall was low and did not vary according to the days after AI, so values were pooled. The overall absorbance values in the muscle layer of the ampulla were: heifers, $0.03 \pm 0.002$ $(n=64)$ and cows, $0.03 \pm 0.004(n=10)$. The equivalent values in the muscular wall of the isthmus were $0.04 \pm$ 0.003 and $0.04 \pm 0.005$, respectively.

\section{Distribution of IGF-1R $m R N A$}

IGF-1R mRNA was present in both the muscle and mucosa of all three oviductal regions (Fig. 1e). In the heifers, there was a trend for higher expression on day 16 after Al (Table 2). Absorbance values measured in cows on day 0 and day 1 were in the same range as those in the heifers (Table 3).

\section{Distribution of IGFBP-1 $m R N A$}

IGFBP-1 mRNA transcripts were not detectable in any of the regions at any time point studied.

\section{Distribution of IGFBP-3 $m R N A$}

Transcripts encoding IGFBP-3 mRNA were detectable in all three oviductal regions tested (Fig. 3). Emulsion-coated slides counterstained with haematoxylin and eosin showed that the IGFBP-3 gene transcripts in the ampulla and isthmus were localized mainly to the luminal epithelium and to the smooth muscle cells (Fig. 2b,c), whereas in the infundibulum the localization was primarily to the subepithelial stroma underlying the luminal epithelium and to the muscle wall.

In both heifers and cows, the strongest expression of IGFBP-3 was observed in the mucosa of the isthmus (Tables 3 and 4). In heifers, there were no differences in expression on the different days studied. In cows, values were similar on day 0 and day 1 . However, a comparison of heifers and cows in relation to the day after oestrus showed consistently higher expression in cows on day 0 and day 1 than in heifers on day 3 , day 6 and day 16 in all regions $(P<0.01)$.

\section{Distribution of IGFBP-5 mRNA}

All three oviductal regions expressed transcripts for IGFBP-5 mRNA (Fig. 3). The strongest hybridization was observed in the muscular layer of both the ampulla and isthmus (Tables 3 and 4). In heifers, IGFBP-5 expression reached a peak on day 6 after $\mathrm{Al}$ in comparison with day 3 and day 16 (Table 4). There was a tendency for IGFBP-5 expression to be higher in cows than heifers, but this difference was less pronounced than for IGFBP-3.

\section{Discussion}

The present study has provided novel data on the localization of the IGF system within different regions of the oviduct in relation to the time of fertilization and the success of early embryonic development. Patterns of localization were very similar between the non-lactating beef cross heifers in study A and lactating dairy cows in study B, and so the two studies are discussed together.

IGF-I gene transcripts in all three oviductal regions were localized mainly to stromal fibroblasts underlying the luminal epithelium in the mucosa and also to the smooth muscle cells of the muscle wall. Previous studies have reported peak expression of IGF-I mRNA in the oviduct near the time of oestrus (bovine, Schmidt et al., 1994; ovine, Stevenson and Wathes, 1996) and the results of the present study are consistent with these reports. Whereas in situ hybridization studies show highest expression in the stroma (present study; Stevenson and Wathes, 1996), Schmidt et al. (1994) and Xia et al. (1996) both reported that IGF-I protein was localized mainly in the epithelial secretory cells. This finding may indicate that the IGF-I detected by immunocytochemistry was attached to a binding protein or receptor, and the results of the present study indicate that binding to IGFBP-3 would be a possibility. The increase in IGF-I gene transcripts near the time of ovulation and in the early luteal phase supports the concept that ovarian oestradiol regulates the expression of IGF-I in the oviduct, as suggested previously for the oviduct of rats (Carlsson et al., 1993), and the uterus in sheep (Stevenson et al., 1994), cattle (Robinson et al., 2000) and pigs (Simmen et al., 1991). As pre-attachment bovine embryos express gene transcripts encoding the type 1 receptor throughout the first week of development (Watson et al., 1992, 1994), IGF-I secreted into oviductal fluid could act as a paracrine regulator of early embryonic cleavage.

The principal site of IGF-II gene transcription was the smooth muscle cells of the muscle wall, whereas IGF-II transcripts were barely detectable in the mucosa of any of the regions examined. The presence of IGF-II mRNA in the oviductal tissue confirms the results of two studies using rtPCR (Kincy et al., 1992; Xia et al., 1996) and the low expression is also in agreement with previous work in ruminants (Stevenson and Wathes, 1996; Xia et al., 1996). On the basis of these observations, it is hard to be persuaded that bovine oviduct cultures release ten times more IGF-II than IGF-I as reported by Winger et al. (1997). The increased content of IGF-II peptide measured in pig oviducts collected during oestrus (Wiseman et al., 1992) could therefore be attributable to increased transudate from 

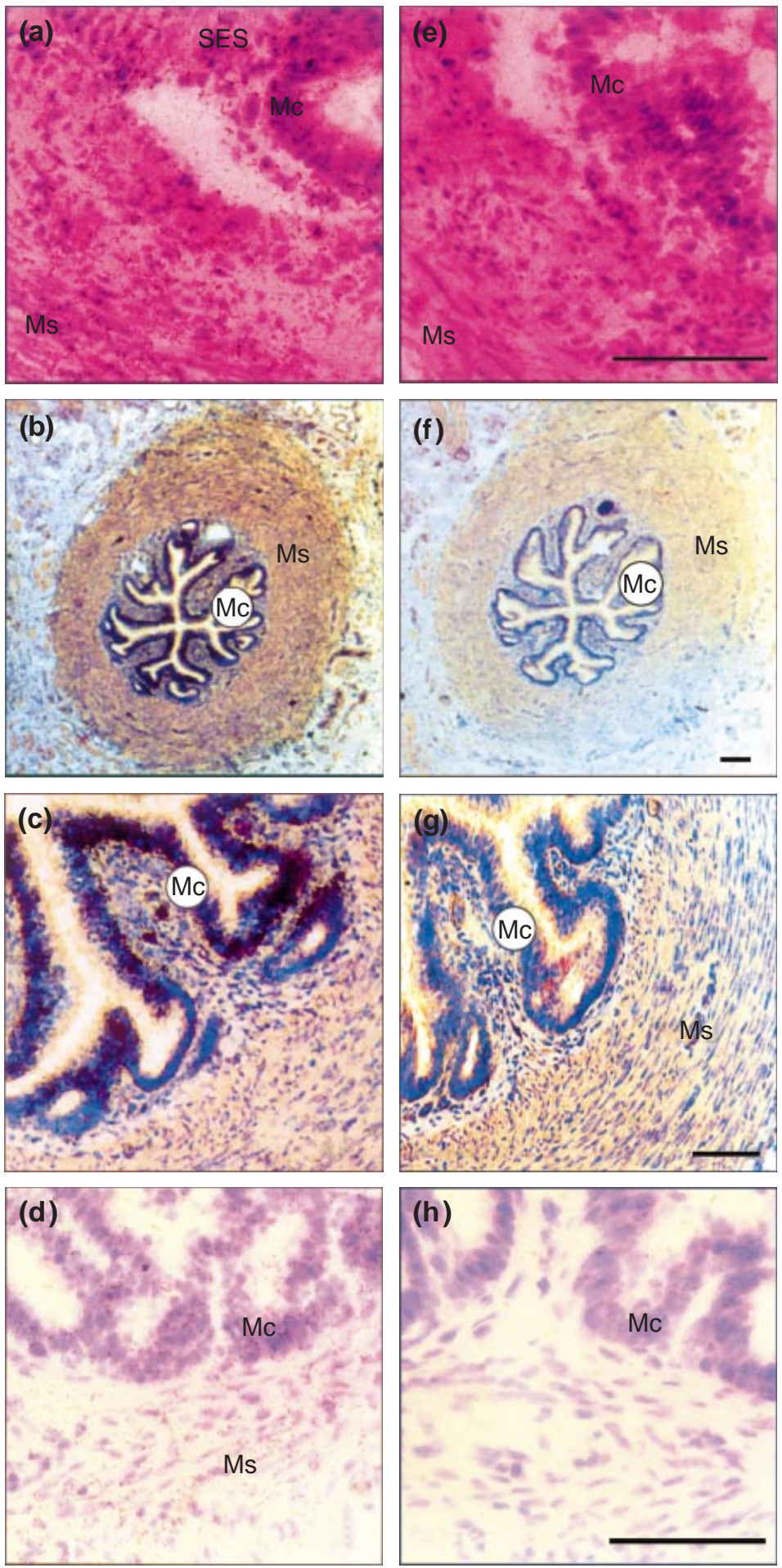

Fig. 2. The distribution of the insulin-like growth factor (IGF) system in the bovine oviduct. The photographs are of emulsion-coated slides counterstained with haematoxylin and eosin to show the cellular localization of IGF-I, IGFBP (binding protein)-3 and -5 mRNAs in the isthmus of the bovine oviduct at oestrus. Sections were probed with either antisense $(\mathrm{a}, \mathrm{b}, \mathrm{c}, \mathrm{d})$ or the corresponding sense oligonucleotides $(\mathrm{e}, \mathrm{f}, \mathrm{g}, \mathrm{h})$ to: (a) IGF-I, (b, c) IGFBP-3 and (d) IGFBP-5 mRNA. The silver grains confirmed the localization of IGF-I mRNA in the mucosa (Mc), sub-epithelial stroma (SES) and underlying smooth muscle layer (Ms). IGFBP-3 mRNA was 
Table 3. Insulin-like growth factor (IGF) system mRNA expression (mean absorbance values \pm SEM) in the oviduct of mature lactating cows in study B

\begin{tabular}{|c|c|c|c|c|c|c|c|c|}
\hline \multirow[b]{3}{*}{ Probe } & \multicolumn{4}{|c|}{ Ampulla } & \multicolumn{4}{|c|}{ Isthmus } \\
\hline & \multicolumn{2}{|c|}{ Mucosa } & \multicolumn{2}{|c|}{ Muscle } & \multicolumn{2}{|c|}{ Mucosa } & \multicolumn{2}{|c|}{ Muscle } \\
\hline & Day 0 & Day 1 & Day 0 & Day 1 & Day 0 & Day 1 & Day 0 & Day 1 \\
\hline IGF-I & $0.05 \pm 0.009$ & $0.05 \pm 0.011$ & $0.03 \pm 0.009$ & $0.05 \pm 0.011$ & $0.06 \pm 0.016$ & $0.06 \pm 0.011$ & $0.05 \pm 0.02$ & $0.06 \pm 0.014$ \\
\hline IGF-1R & $0.05 \pm 0.006$ & $0.06 \pm 0.007$ & $0.06 \pm 0.008$ & $0.07 \pm 0.009$ & $0.06 \pm 0.011$ & $0.07 \pm 0.007$ & $0.05 \pm 0.014$ & $0.04 \pm 0.009$ \\
\hline IGFBP-3 & $0.15 \pm 0.039$ & $0.16 \pm 0.048$ & $0.19 \pm 0.042$ & $0.17 \pm 0.051$ & $0.58 \pm 0.119$ & $0.39 \pm 0.146$ & $0.19 \pm 0.050$ & $0.20 \pm 0.062$ \\
\hline IGFBP-5 & $0.11 \pm 0.012$ & $0.08 \pm 0.014$ & $0.23 \pm 0.022$ & $0.19 \pm 0.027$ & $0.07 \pm 0.016$ & $0.07 \pm 0.065$ & $0.31 \pm 0.019$ & $0.30 \pm 0.080$ \\
\hline
\end{tabular}

*Samples were collected from six cows on the day of oestrus (day 0) and from four cows on the following day (post ovulation, day 1 ). There were no significant differences between these two time points.

IGF-1R: type 1 IGF receptor; IGFBP: IGF binding protein.

the plasma and/or transport of the translated gene product from its main local site of production (the muscle wall) to the oviduct lumen.

The distribution of IGF-1R in both the mucosa and muscle of the bovine oviduct was similar to that described for sheep (Stevenson and Wathes, 1996). The IGF-1R in the mucosa may participate in the increased secretory activity of the epithelial cells that occurs during oestrus and the early luteal phase in various species (Wiseman et al., 1992; Murray, 1996; Makarevich and Sirotkin, 1997), whereas the IGF-1R in the muscle may contribute to the enhanced contractility of the oviduct at oestrus (Ruckebusch and Bayard, 1975; Gilbert et al., 1992). Makarevich and Sirotkin (1997) also demonstrated that both growth hormone and IGF-I stimulated cAMP production by cultured bovine oviductal cells, whereas PGF $_{2 \alpha}$ release was inhibited.

In the present study, it was demonstrated that the bovine oviduct expresses IGFBP-3 and -5 mRNAs, whereas IGFBP-1 mRNA was not detected at any of the time points investigated. These results are in agreement with observations for bovine oviduct cultures (Winger et al., 1997). The strongest expression of IGFBP-3 mRNA was in the epithelial lining of the isthmus during oestrus. The localization was similar in the ampulla, although the concentration was lower, whereas in the infundibulum, expression of IGFBP-3 mRNA was predominantly in the sub-epithelial stroma of the mucus membrane. These observations indicate both that there may be region-specific expression of IGFBP-3 and that this binding protein may help to regulate the concentration of IGF-I in the oviductal fluid. This pattern of distribution might help to create an IGF-I gradient along the oviduct as the embryo travels through it.

In the present study, expression of IGFBP-3 mRNA was markedly higher in the samples collected from cows at oestrus and on day 1 compared with the luteal phase samples obtained from the heifers on day 3, day 6 and day 16 after Al. Peak expression of IGFBP-3 mRNA at oestrus is also in agreement with the situation reported previously in the ovine oviduct (Stevenson and Wathes, 1996), indicating that the variation was due to the stage of the oestrous cycle or pregnancy rather than to the type of cow. However, studies on the bovine uterus did not show an effect of the stage of oestrous cycle, but there were differences in the expression pattern of IGFBP-3 mRNA in endometrial biopsy samples obtained during the luteal phase from two groups of cows, indicating that the difference might be related to the lactational or nutritional status of the animals (Robinson et al., 2000). The actions of IGFBP-3 on IGF-I are generally inhibitory, although potentiating effects have also been described (for reviews, see Rechler, 1993; Rechler and Clemmons, 1998). If expression of IGFBP-3 mRNA in the uterus and oviduct of cows is indeed regulated by nutrition, it is possible that increased concentrations of IGFBP-3 may be present in early lactation when dairy cows are in negative energy balance (Beam and Butler, 1999) and that this could inhibit actions of IGF-I on the reproductive tract. This suggestion cannot be resolved from the present set of data and warrants further investigation.

During the oestrous cycle, IGFBP-5 mRNA was localized predominantly to the smooth muscle cells in both the ampulla and isthmus. Similarly, Winger et al. (1997) reported that primary cultures of bovine oviduct expressed IGFBP-5 mRNA throughout an 8 day culture period and that oviductal monolayers and vesicular cultures released IGFBP-5. In the ovine uterus, IGFBP-5 concentrations were highest in the luminal epithelium and caruncular stroma, with moderate to low expression in the inner myometrium and endometrial stroma, respectively (Gadd et al., 2000). The reason for the increased expression in the heifers on day 6 after $\mathrm{Al}$ is uncertain.

Several studies on cows have investigated the relationship between the uterine IGF system and the establishment of pregnancy (Geisert et al., 1991; Kirby et al., 1996; Keller et al., 1998; Robinson et al., 2000). Although the results

expressed strongly in the mucosa, whereas IGFBP-5 mRNA was expressed predominantly in the smooth muscle of the oviduct. Scale bars represent $500 \mu \mathrm{m}$. 

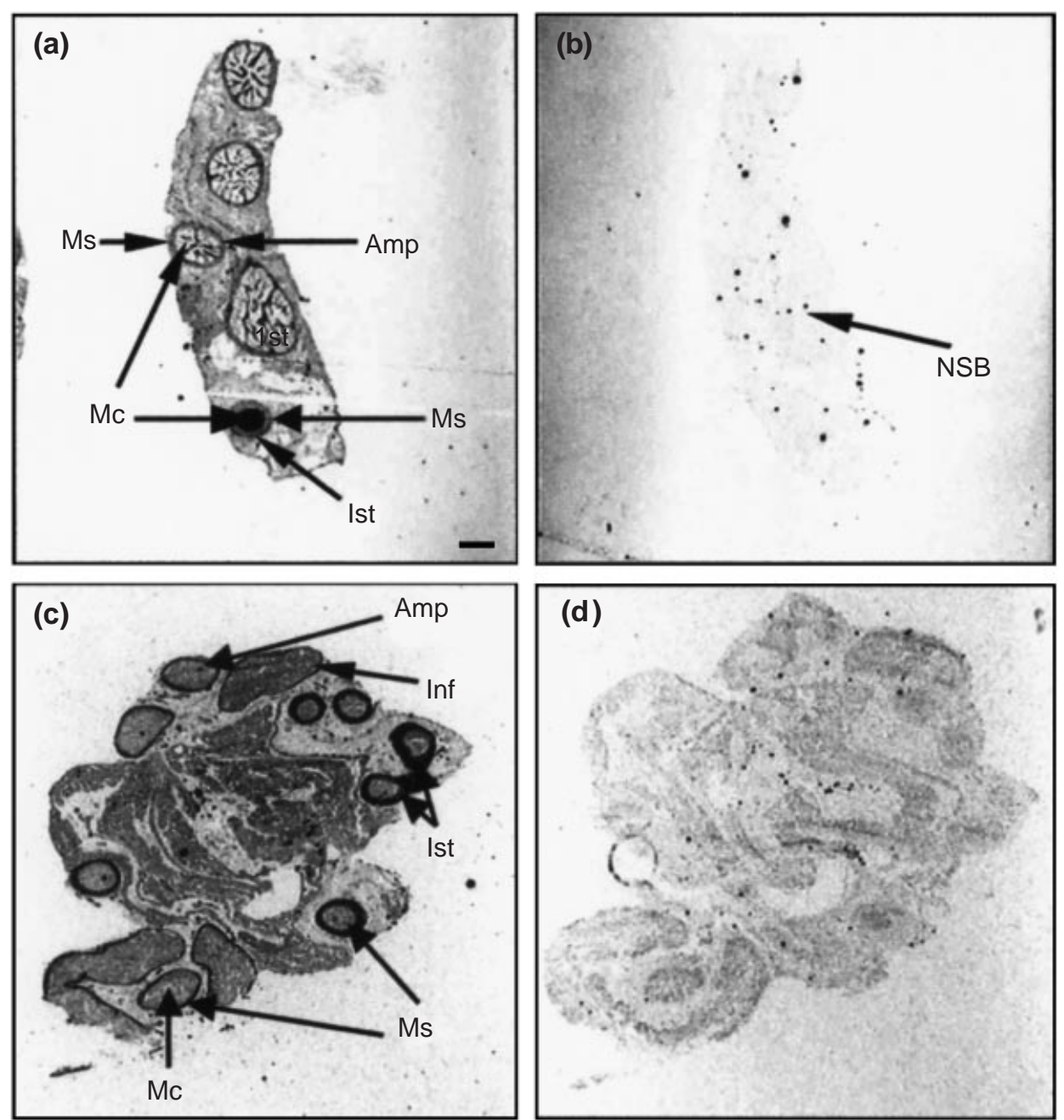

Fig. 3. In situ hybridization showing localization of mRNA encoding: (a) insulin-like growth factor binding protein (IGFBP)-3 and (c) IGFBP-5 in the bovine oviduct at oestrus. Sections (b) and (d) are corresponding sense oligonucleotides to IGFBP-3 and -5 mRNA. The strongest hybridization of IGFBP-3 mRNA was detected during oestrus in the mucosa (Mc) and muscle (Ms) of the isthmus (Ist) and ampulla (Amp), respectively. The transcripts for IGFBP-5 mRNA were observed predominantly in the muscular layer and the mucosa also expressed detectable amounts of IGFBP5 mRNA transcripts. NSB: non-specific binding. Scale bar represents $2 \mathrm{~mm}$.

were not entirely consistent, there was a trend towards higher expression of IGF-I and IGFBP-1 mRNA and lower amounts of IGFBP-2 and -3 mRNA in the uteri of pregnant compared with non-pregnant cows in the late luteal phase (days 16-17). This finding may indicate that cows in better nutritional status have an increased likelihood of establishing a pregnancy or that there is a local effect of the embryo on the IGF system. In the present study, there was no observed effect on the oviductal IGF system associated with the presence or absence of an embryo. However, it is possible that an effect of nutrition could influence the suitability of the oviduct for early embryo development via alterations in circulating IGF-I (Breier et al., 1988; McGuire et al., 1992).
In conclusion, the present study has illustrated the spatial and temporal distribution of the IGF system in the bovine oviduct. Locally or systemically produced IGF-I may regulate embryo development directly (via secretion into the oviductal lumen) and indirectly (via actions on the IGF$1 \mathrm{R}$ present on the mucosal secretory cells). As mRNAs encoding IGF-I and -II and IGF-1R were all present in the muscle wall, local production of these peptides may modulate the muscular contractility of the oviduct. The contraction of the oviduct could in turn affect the movement of the egg, spermatozoa and embryo. The presence of IGFBP-3 and -5 may regulate the transfer of IGFs into the oviductal lumen and influence the action of IGFs on the oviduct mucosa and musculature. 
Table 4. Insulin-like growth factor binding protein (IGFBP)-3 and IGFBP-5 mRNA expression (mean absorbance values) in the oviduct of heifers in study $\mathrm{A}$

\begin{tabular}{clccccc}
\hline Region & Tissue & Day 3 & Day 6 & Day 16 & Pooled SE & $P<$ cycle \\
\hline \multirow{2}{*}{ IGFBP-3 $(n)$} & & $(24)$ & $(24)$ & $(16)$ & & \\
Ampulla & Mucosa & 0.04 & 0.05 & 0.06 & 0.005 & 0.53 \\
& Muscle & 0.08 & 0.08 & 0.09 & 0.007 & 0.90 \\
Isthmus & Mucosa & 0.21 & 0.25 & 0.27 & 0.019 & 0.39 \\
& Muscle & 0.08 & 0.10 & 0.09 & 0.009 & 0.38 \\
\multirow{2}{*}{ IGFBP-5 $(n)$} & & & & & & \\
Ampulla & Mucosa & 0.06 & 0.07 & 0.07 & 0.003 & 0.06 \\
& Muscle & $0.13^{\mathrm{a}}$ & $0.18^{\mathrm{b}}$ & $0.15^{\mathrm{a}}$ & 0.006 & 0.002 \\
Isthmus & Mucosa & $0.05^{\mathrm{a}}$ & $0.09^{\mathrm{b}}$ & $0.07^{\mathrm{a}}$ & 0.004 & 0.001 \\
& Muscle & $0.22^{\mathrm{a}}$ & $0.37^{\mathrm{b}}$ & $0.28^{\mathrm{a}}$ & 0.011 & 0.0001 \\
\hline
\end{tabular}

${ }^{a b}$ Within rows, values with different superscripts are significantly different, $P<0.05$.

The number of animals $(n)$ studied at each stage for each probe is indicated.

This study was funded by the Department for Environment, Food and Rural Affairs and by the Scottish Executive Rural Affairs Department. P. G. A. Pushpakumara was supported by a Commonwealth Scholarship. The authors thank P. Dawuda for provision of the cow oviducts in study B, and B. Wilsmore for photography.

\section{References}

Bavister BD (1988) Role of oviductal secretions in embryonic growth in vitro and in vivo. Theriogenology 29 143-155

Beam SW and Butler WR (1999) Effect of energy balance on follicular development and first ovulation in post partum dairy cows Journal of Reproduction and Fertility Supplement 54 411-424

Breier BH, Gluckman PD and Bass JJ (1988) Influence of nutritional status and oestradiol-17 $\beta$ on plasma growth hormone, insulin-like growth factors-I and -II and the response to exogenous growth in young steers Journal of Endocrinology 118 243-250

Bulman DC and Lamming GE (1978) Milk progesterone levels in relation to conception, repeat breeding and factors influencing acyclicity in dairy cows Journal of Reproduction and Fertility 54 447-458

Camous S, Heyman Y, Meziou W and Menezo Y (1984) Cleavage beyond the block stage and survival after transfer of early bovine embryos cultured with trophoblastic vesicles Journal of Reproduction and Fertility 72 479-485

Carlsson B, Hillensjo T, Nilsson A, Tornell J and Billig H (1993) Expression of insulin-like growth factor-I (IGF-I) in the rat Fallopian tube: possible autocrine and paracrine action of Fallopian tube-derived IGF-I on the Fallopian tube and on the preimplantation embryo Endocrinology 133 2031-2039

Daughaday WH and Rotwein P (1989) Insulin-like growth factors I and II peptide, messenger ribonucleic acid and gene structures, serum, and tissue concentrations Endocrine Reviews 10 68-91

Dalton T, Kover K, Dey SK and Andrews GK (1994) Analysis of the expression of growth factor, interleukin-1 and lactoferrin genes and the distribution of inflammatory leukocytes in the preimplantation mouse oviduct Biology of Reproduction 51 597-606

Gadd TS, Osgerby JC and Wathes DC (2000) Regulation and localization of insulin-like growth factor binding protein-5 gene expression in the uterus and placenta of the cyclic and early pregnant ewe Biology of Reproduction 62 1415-1421

Geisert RD, Lee CY, Simmen FA, Zavy MT, Fliss AE, Bazer FW and Simmen RC (1991) Expression of messenger RNAs encoding insulin-like growth factor-I, -II and insulin-like growth factor binding protein-2 in bovine endometrium during the estrous cycle and early pregnancy Biology of Reproduction 45 975-983

Gilbert CL, Cripps PJ and Wathes DC (1992) The effect of oxytocin on the pattern of electromyographic activity in the oviduct and uterus of the ewe around oestrus Reproduction, Fertility and Development 4 193-203

Giudice LC, Dsupin BA, Irwin JC and Eckert RL (1992) Identification of insulin-like growth factor binding proteins in human oviduct Fertility and Sterility 57 294-301

Herrler A, Lucas-Hahn A and Niemann H (1993) Effects of insulin-like growth factor-I on in vitro production of bovine embryos Theriogenology 37 1213-1224

Heyner S (1997) Growth factors in preimplantation development: role of insulin and insulin-like growth factors Early Pregnancy 3 153-163

Hunter RHF (1988) The Fallopian Tubes: Their Role in Fertility and Infertility Springer-Verlag, Berlin

Jones JI and Clemmons DR (1995) Insulin-like growth factors and their binding proteins: biological actions Endocrine Reviews 16 3-134

Kaye PL, Bell KL, Beebe FS, Dunglison GF, Gardner HG and Harvey MB (1992) Insulin and the insulin-like growth factors (IGFs) in preimplantation development Reproduction, Fertility and Development 4 373-386

Keller ML, Roberts AJ and Seidel GE (1998) Characterization of insulin-like growth factor binding proteins in the uterus and conceptus during early conceptus elongation in cattle Biology of Reproduction 59 632-642

Kincy VL, Williams JE and Butler JE (1992) Expression of the insulin-like growth factor II (IGF-II) gene by ovine oviductal cells Biology of Reproduction 46 (Supplement 1) 67

Kirby CJ, Thatcher WW, Collier RJ, Simmen FA and Lucy MC (1996) Effects of growth hormone and pregnancy on expression of growth hormone receptor, insulin-like growth factor-I and insulin-like growth factor binding protein-2 and -3 genes in bovine uterus, ovary and oviduct Biology of Reproduction 55 996-1002

Larson RC, Ignotz GG and Currie WB (1992) Transforming growth factor beta and basic fibroblast growth factor synergistically promote early bovine embryo development during the fourth cell cycle Molecular Reproduction and Development 33 432-435

LeRoith D, Werner H, Beitner-Johnson D and Roberts CT (1995) Molecular and cellular aspects of the insulin-like growth factor I receptor Endocrine Reviews 16 143-163

McGuire MA, Vicini JL, Bauman and Veenhuizen JJ (1992) Insulin-like growth factors and binding proteins in ruminants and their nutritional regulation Journal of Animal Science 70 2901-2910

Makarevich AV and Sirotkin AV (1997) The involvement of the GH/IGF-I axis in the regulation of secretory activity by bovine oviduct epithelial cells Animal Reproduction Science 48 197-207 
Moser DR, Lowe Jr, WL, Dake BL, Booth BA, Boes M, Clemmons DR and Bar RS (1992) Endothelial cells express insulin-like growth factorbinding proteins 2 to 6 Molecular Endocrinology 6 1805-1814

Murphy LJ, Murphy LC and Friesen HG (1987) Estrogen induces insulin-like growth factor-I expression in the rat uterus Molecular Endocrinology 1 $445-450$

Murray MK (1996) Changes in secretory status, cell height and percentage ciliation of epithelial lining of sheep fimbria oviduct during early pregnancy Journal of Reproduction and Fertility 106 173-183

O'Mahoney JV and Adams TE (1989) Nucleotide sequence of an ovine insulin-like growth factor-II cDNA Nucleic Acids Research 175392

Palma GA, Muller M and Brem G (1997) Effects of insulin-like growth factor I (IGF-I) at high concentrations on blastocyst development of bovine embryos produced in vitro. Journal of Reproduction and Fertility 110 347-353

Rechler MM (1993) Insulin-like growth factor binding proteins Vitamins and Hormones 47 1-114

Rechler MM and Clemmons DR (1998) Regulatory actions of insulin-like growth factor binding proteins Trends in Endocrinology and Metabolism 9 176-183

Rechler MM and Nissley SP (1985) The nature and regulation of the receptors for insulin-like growth factors Annual Review of Physiology 47 425-442

Roberts AJ, Nugent RA, Klindt J and Jenkins TG (1997) Circulating insulinlike growth factor I, insulin-like growth factor binding proteins, growth hormone, and resumption of estrus in postpartum cows subjected to dietary energy restriction Journal of Animal Science 75 1909-1917

Robinson RS, Mann GE, Gadd TS, Lamming GE and Wathes DC (2000) The expression of the IGF system in the bovine uterus throughout the oestrous cycle and early pregnancy Journal of Endocrinology 165 231-243

Ruckebusch Y and Bayard F (1975) Motility of the oviduct and uterus of the cow during the oestrous cycle Journal of Reproduction and Fertility 43 23-32

Scharf J, Ramadori G, Braulke T and Hartmann H (1996) Synthesis of insulin like growth factor binding proteins and of the acid-labile subunit in primary cultures of rat hepatocytes, of Kupffer cells, and in cocultures: regulation by insulin, insulin like growth factor, and growth hormone Hepatology 23 818-827

Schmidt A, Einspanier R, Amselgruber W, Sinowatz F and Schams D (1994) Expression of insulin-like growth factor I (IGF-I) in the bovine oviduct during the oestrous cycle Experimental Clinical Endocrinology 102 364-369

Simmen RCM, Simmen FA, Hofig A, Farmer SJ and Bazer FW (1991) Hormonal regulation of insulin-like growth factor gene expression in pig uterus Endocrinology 127 2166-2174

Sneyers M, Kettmann R, Massart S, Renaville R, Burny A and Portetelle D (1991) Cloning and characterization of a cDNA encoding the bovine insulin-like growth factor binding protein 1 (blGFBP-1) Journal of DNA Sequencing and Mapping 6 407-408

Spratt SK, Tatsuno GP and Sommer A (1991) Cloning and characterization of bovine insulin-like growth factor binding protein-3 (blGFBP-3) Biochemical and Biophysical Research Communications 177 1025-1032
SPSS Inc. (Version 9) Headquarters, 2335, Wacker Drive, 11th Floor Chicago, IL 60606

Stevenson KR and Wathes DC (1996) Insulin-like growth factors and their binding proteins in the ovine oviduct during the oestrous cycle Journal of Reproduction and Fertility 108 31-40

Stevenson KR, Gilmour RS and Wathes DC (1994) Localization of insulinlike growth factor-I (IGF-I) and -II messenger ribonucleic acid and type 1 IGF receptors in the ovine uterus during the estrous cycle and early pregnancy Endocrinology 134 1655-1664

Ullrich A, Gray A, Tam AW et al. (1986) Insulin-like growth factor I receptor primary structure: comparison with insulin receptor suggests structural determinants that define functional specificity $E M B O$ Journal 5 2503-2512

Wathes DC (1982) Embryonic mortality and the uterine environment Journal of Endocrinology 134 321-325

Watson AJ, Hogan A, Hahnel A, Wiemer KE and Schultz GA (1992) Expression of growth factor ligand and receptor genes in the preimplantation bovine embryo Molecular Reproduction and Development $3187-95$

Watson AJ, Watson PH, Arcellana-Panlilio M, Warnes D, Walker SK, Schultz GA, Armstrong DT and Seamark RF (1994) A growth factor phenotype map for ovine preimplantation development Biology of Reproduction $\mathbf{5 0} 725-733$

Winger QA, de los Rios P, Han VK, Armstrong DT, Hill DJ and Watson AJ (1997) Bovine oviductal and embryonic insulin-like growth factor binding proteins: possible regulators of "embryotrophic" insulin-like growth factor circuits Biology of Reproduction 56 1415-1423

Wiseman DL, Henricks DM, Eberhardt DM and Bridges FW (1992 Identification and content of insulin-like growth factors in porcine oviductal fluid Biology of Reproduction 47 126-132

Wong EA, Ohlsen SM, Godfredson JA, Dean DM and Wheaton JE (1989) Cloning of ovine insulin-like growth factor-I cDNAs: heterogeneity in the mRNA population DNA $9649-657$

Xia P, Tekpetey FR and Armstrong DT (1994) Effect of IGF-I on pig oocyte maturation, fertilisation, and early embryonic development in vitro, and on granulosa and cumulus cell biosynthetic activity Molecular Reproduction and Development 38 373-379

Xia P, Han VK, Viuff D, Armstrong DT and Watson AJ (1996) Expression of insulin-like growth factors in two bovine oviductal cultures employed for embryo co-culture Journal of Endocrinology 149 41-53

Zapf J and Froesch ER (1986) Insulin-like growth factors/somatomedins: structure, secretion, biological actions and physiological role Hormone Research 24 121-130

Zhao Y, Chegini N and Flanders KC (1994) Human Fallopian tube expresses transforming growth factor (TGF beta) isoforms, TGF beta type I-III receptor messenger ribonucleic acid and protein, and contains [125I]TGF beta binding sites Journal of Clinical Endocrinology and Metabolism 79 1177-1184

Received 5 November 2001.

First decision 4 January 2002.

Revised manuscript received 8 February 2002.

Accepted 14 February 2002. 